\title{
A Stylistic Analysis of Linguistic Patterns in Chichamanda Ngozi Adichie's Purple Hibiscus
}

\author{
Muchamad Sholakhuddin Al Fajri (Corresponding author) \\ Lancaster University, United Kingdom \\ E-mail: s.alfajri@lancaster.ac.uk
}

Doi:10.7575/aiac.alls.v.8n.3p.55

Received: 07/04/2017

URL: http://dx.doi.org/10.7575/aiac.alls.v.8n.3p.55

Accepted: 12/06/2017

The research is financed by Indonesia Endowment Fund for Education (LPDP)

\begin{abstract}
This study aims to carry out a detailed and systematic stylistic analysis of linguistic patterns in Purple Hibiscus Novel by Chichamanda Ngozi Adichie. It particularly analyses a specific extract of the novel in terms of narration and point of view, conversational analysis, speech and thought presentations and mind style, and how these linguistic devices and patterns are employed by the author to shape characters' personalities and relationships between them in the reader's mind. The result appears to suggest that the author successfully represents the protagonist, Kambili as an obedient and a salient daughter who respects deeply his father, while her father, Eugene, is constructed as a strict father and religious who imposes an absolute control on his daughter.
\end{abstract}

Keywords: Characterization, Purple Hibiscus, point of view, speech presentation, thought presentation, mind style

\section{Introduction}

Stylistics generally can be defined as the study of language style and linguistic patterns used in a (literary) text. The chief aims of a stylistic analysis are "to explore creativity in language use" in order to understand (literary) texts (Simpson, 2014: p. 3) and to describe the connection between language and artistic function (Leech \& Short, 1981, 2007). Most of stylistic studies have investigated 'a certain aspect' of style in a particular fictional text such as Guo's (2017) analysis of 'thought presentation' in Mr. Dalloway, Abdurrahman's (2016) study of 'complexity of sentence' in A Rose for Emily and Teranishi's (2007) research on 'speech and thought presentation involved in the protagonist characterization' in Herzog.

This present study, however, is distinct from the previous studies in the sense that it investigates several linguistic aspects, rather than only 'one particular feature'. More specifically, this paper is an endeavor to conduct a systematic stylistic analysis of an extract of a novel entitled Purple Hibiscus written by a Nigerian novelist, Chichamanda Ngozi Adichie (Adichie, 2003). The full extract can be found in the appendix. The novel Purple Hibiscus largely portrays issues of Catholic faith in private and public spheres, and emphasizes the detrimental effects of patriarchy and intolerance in the family, the church and the state, postcolonial Nigeria (Stobie, 2010). The novel's main protagonist is Kambili, a fifteen-year old Nigerian girl. She lives with her father, Eugene, who imposes his fanatical religious views on the family home (Tunca, 2009). Eugene is a strict father who values strict discipline, seems intolerant and plays a dominant role in the family. The values are based on his own strict interpretation of his religious teachings. Later in the story, Kambili becomes more open and has the courage to challenge her father's ideological views.

The prime aim of this study is to provide linguistic evidence that shows how linguistic devices and patterns are used by the author to form personalities of the characters and relationships between them in readers' mind. It will begin with the description of the data and method before providing the analysis and discussion. In the last section, a conclusion of this study will be presented.

\section{Data and Method}

The extract that is utilized in this present study describes the beginning of the novel in which Kambili was still a shy and quiet girl. It presents disappointment of Eugene (henceforth Papa) to his daughter, Kambili, because her exam results showed that she came second in her class. Papa demanded that his children must come first in every school term. Papa, therefore, decided to drive her to the school on the first day of the new term. Papa then expressed his dissatisfaction in the front of Kambili's class.

This research employs a descriptive qualitative method. It provides a detailed analysis in terms of narration and point of view (Short, 1996; Fowler, 1996), conversational analysis which deals with turn-taking patterns and pragmatic features, speech and thought presentations (Short, 1996; Semino \& Short, 2004) and mind style (Fowler, 1996; Semino, 2002). The analysis of these linguistic devices is aimed at seeing how the author exercises linguistic tools to shape characters' 
personalities and relationships between them in the reader's mind. This study thus may help us understand better the literary text and the use of linguistic patterns in it.

\section{Analysis and Discussion}

\subsection{Narration and Point of View}

The novel is narrated from the point of view of a first-person narrator or what Short (1996) calls "I-narrator". Kambili, who is also a character in this novel, is the narrator and therefore the events that take place are seen from her perspective. In other words, the reader perceives the events and the other characters only through her eyes and based on her interpretation. Unlike third-person narrators who are typically omniscient, first-person narrators canonically have limited knowledge (Short, 1996). Kambili, for example, does not have privilege access into her father's internal stances. This can be seen in (1) and (2). In these instances, Kambili questions about what her father wants to do in the school, thus indicating knowledge limitation. It should be noted, however, that a third-person narrator sometimes also asks questions in order to create mystery and suspense (Short, 1996: p. 260). In the remainder of this section, I will attempt to provide some of the linguistic devices that indicate a point of view.

(1) Was Papa going to talk to her? Yank at her ears for coming first?

(2) I wondered what he was doing, why he was here, why he had driven me to school and asked Kevin to take Jaja.

First, a point of view can be indicated through the notion of deixis. Deixis is a linguistic term that is used to denote to "pointing expressions" which are related to the speaker (Short, 1996: p. 269). This may be related to the spatial and temporal dimension of viewpoint proposed by Fowler $(1986 ; 1996)$. The spatial point of view is connected to spatial deictic expressions which suggest a spatial position relative to the speaker, while the temporal viewpoint is related to temporal deixis, indicating the time when the event or narration occurs. Examples of spatial deixis in the extract can be found in (2) and (3). In these two sentences, spatial deixis is realized through the deictic adverb here and the demonstrative pronoun this respectively, which indicate closeness to Kambili as character. Additionally, spatial deixis can be realized by using locative expressions such as in front of in (4), into, near and beyond in (5), which can "serve to anchor the viewing position as that of the narrating subject" (Simpson, 1993: p. 16). In such way, spatial viewpoint can serve to place the reader in a position of the deictic center, in this case Kambili, and therefore the reader perceives objects, events and actions in the fictional world from her angle. Temporal point of view, on the other hand, come through the adverb before in (3) and next week in (6), which suggest remoteness to the time of speaking. The tense that is used may also function as a temporal deixis. All the first-person narrative is in the past either in the past tense or past perfect, thus indicating that the events referred to are remote to the moment of utterance.

(3) I had heard this all before...

(4) I had chosen to come to school to have a long conversation in front of the classroom building.

(5) Papa finally eased the car into the wide school compound and parked near the volleyball court, beyond the stretch of manicured lawn.

(6) would he be at the reception for the bishop next week?

Furthermore, novelists can indicate a point of view through evaluative words or "value-laden expressions" (Short, 1996: p. 265). For example, the adverb gaily and generously in (7) and (8) respectively and the adjective gracious in (9) and light-skinned in (10) can help show that the evaluation is from the viewpoint of Kambili. The next indicator is a particular character's thoughts or perceptions. This can be realized by employing cognitive, perceptive and factive verbs such as the verb wondered in (2), heard in (3), taste in (11) and watching in (12). Modality such as could in (11) and would in (13) can also suggest a viewpoint. These cognitive and modal verbs serve to signal that the description of the scene is from Kambili's point of view.

(7) She waved gaily, from the midst of students and a few parents ...

(8) Her (Sister Margaret) words flew generously out of her mouth.

(9) He (Papa) was gracious. . .

(10) Chinwe's light-skinned face was at the center of the group, as usual.

(11) I could taste the sand that settled on my lips.

(12) I was watching him walk down the path bordered by flowerless green bushes when the assembly bell rang.

(13) ... things he would never have learned from his idol-worshiping father, my Papa-Nnukwu.

Moreover, two previous linguistic indicators, value-laden expressions and modal auxiliaries can also suggest what Fowler (1996) calls "ideological plane of point of view". It is the set of values or the system of beliefs possessed by an individual or a society to comprehend the world (ibid). A variety of modal structures and evaluative words are used by the author to describe characters' ideological viewpoint in a more direct or an explicit way. Yet, the author can also indicate the world views of characters indirectly or in a less direct way by employing a transitivity structure, a part of ideational metafunction in Systemic Functional Grammar proposed by Halliday (1985, 1994). For example, Papa presents the agency of God in sentence (14) and (15), which indicates his belief in a religion, to express the reason why Kambili has to come first. His demand for Kambili to achieve the first rank in the class is also manifested in the modal verb have to in (16), which has the additional meaning of obligation or necessity. The subject "God" in (15) is also assigned to the mental processes expects with the "extreme" noun perfection as the phenomenon. In such way, these sentences might help the reader infer that Papa has strict interpretation of religious values, suggesting his ideological viewpoint. 
(14) "Because God has given you much, he expects much from you."

(15) "He expects perfection."

(16) "You have to do something with all these privileges."

The last linguistic means of indicating a point of view that seems important to be discussed is definite and indefinite articles. According to Short (1996), the use of definite and indefinite reference can suggest whether we take into account our addressee's viewpoint or not. Definite reference is applied to refer to something that is already mentioned previously in the text, while indefinite reference is used to refer to new information or something which is not known by the reader. However, the author sometimes employs definite reference to refer to new information. For example, the definite article the is used in (5) when mentioning the first time "wide school compound", "volleyball court" and "stretch of manicured lawn". This is used in order to position the reader as already 'in the know' or in the middle of the action (Short, 1996: p. 267. Nevertheless, definite reference can also be applied to introduce rather insignificant entities, shaping the background of the scene, while indefinite reference is used to present important entities (Semino, 1997). Therefore, in sentence (17), the author chooses to use the indefinite article to introduce "small mirror" which relatively plays an important role in the extract.

(17) Papa pulled $a$ small mirror, the size of a powder compact, from his pocket.

\subsection{Conversation Analysis}

Although the dialogue between the two main characters, Kambili and Papa, is not very extensive in the extract, it seems that it contributes enormously to the construction of their personalities and relationships. In this section, I will try to investigate the way the personalities of the characters and the relations between them are highlighted through conversational patterns.

\subsubsection{Turn Taking Patterns}

Analyzing the turn-taking system which organizes and manages contributions of the interlocutors is an effective way to understand the overall character relations in a conversation (Short, 2014) as it is closely connected to conversational power (Short, 1996). In the extract, there are only two characters involved in the dialogue and therefore we can expect equal numbers of turns. Indeed, Both Papa and Kambili have ten speech turns. However, it should be noted that in four of Kambili's turns, she does not respond to Papa's statement, question or command by verbal expressions but 'merely' by body language. It can be seen in (18), (19), (20) and (21). This therefore may contribute to the representation of Kambili as a quiet and very submissive to her father. Additionally, the conjunction but in two of her non-verbal communications, nodded and looked alert in (21) and looked at Chinwe Jideze in (22), suggests that they are not default responses but she chooses to do them. These scenes then might help us to infer that these responses are her shows of respect for her father, thus serving to construct Kambili as an obedient daughter.

(18) I pointed to the building by the group of mango trees.

(19) I stared at him.

(20) I took the mirror, peered at it.

(21) But I nodded and looked alert.

(22) I did not need to look at her to know that, but I looked at her, anyway.

Furthermore, they have a marked difference in the average of words per turn. Papa has an average of 18.5 per turn and Kambili 3.2, suggesting that there is radical difference in power. This power relation becomes more salient when we take initiation/response patterns into account. Papa consistently initiates the exchange and controls the topic, while Kambili just responds to it. Indeed, all Papa's speech turns can be categorized as initiations and all Kambili's turns are responses. Thus, it seems that Papa is by far the powerful speaker.

The term of address that is used in the dialogue can also suggest social relations between the characters (Short, 1996, 2014). The father refers to Kambili by second-person pronoun you and once by igbo. The narrator, on the other hand, always addresses her father by the family term Papa with capital "P" although the word is not in the beginning of a sentence. This is likely to be an instance of graphological deviation which may be applied to highlight the lack of intimacy or remoteness in their relationship. Furthermore, interruptions that occur in a conversation can also indicate conversational power, in which frequently the more powerful speakers interrupt the less powerful (Short, 2014). In the present extract, nevertheless, there are no interruptions whatsoever, which may suggest that Kambili conforms straightforwardly to Papa's initiations. However, it might be important to note that in two parts of the conversational exchange, Kambili seems not to give preferred responses. First, when Papa asks her to "look in the mirror" but she responds by staring at him in (19). Her response is considered as dispreferred by Papa so that he re-initiates again his command. The second one is when Papa questions her about the reason for letting Chinwe Jideze come first in (23). Her response in (24) appears not actually answer the question asked. These two responses will be further discussed in the next subsection.

(23) "So why did you let her come first?"

(24) "It will not happen again, Papa."

\subsubsection{Pragmatic Features: Speech Acts, Politeness, Grice's Cooperative Principle}

There are clear differences in terms of speech acts performed by two characters. Most of Papa's turns are questions and commands, while most of Kambili's are statements which represent her answers to her father's questions and her acceptances of the instructions given. Papa's speech acts therefore achieve their perlocutionary effects somewhat 
straightforwardly. The only exception to this is when Papa orders her to look in the mirror in (25) but she does not directly obey the command by staring at him. This might indicate Kambili's silent protest, thus foregrounding her silent character. Moreover, Papa's commands are always in the form of direct speech acts, which are realized by exercising imperative structures as exemplified in (25) and (26). In the notion of Politeness proposed by Brown and Levinson $(1978,1987)$, such direct command is seen as a face threatening act since it impedes Kambili's wish to do something else, attacking baldly her negative face. Papa even does not have an intention to mitigate the amount of threat because when his first attempt to ask Kambili to look in the mirror is failed, he restates his command with the same imperative sentence. However, this cannot be automatically seen as an antithesis of politeness. This might be normally expected since in terms of kinship Papa as her father has considerable power over Kambili, her teenage daughter. Kambili, on the other hand, is polite to her father, as indicated by her use of the address term Papa. These patterns then might also reflect clear-cut relationship between father and daughter.

(25) "Look in the mirror."

(26) "Look at her," Papa said.

In terms of the cooperative principle (Grice, 1975, 1989, 2011), several Papa's utterances tend to break Grice's maxims. Papa's questions in (27), (28) and (29) seem to break the maxim of quality, which says that the speaker should be sincere and truthful (Cutting, 2008). Here, in (27), (28), Papa is not likely to sincerely ask the questions because naturally he has already known the answer. He has known that both Kambili and Chinwe Jideze have one head. The key role of the two questions is apparently as a bridge to his point of argument in (30). Kambili, however, does not spot his implicit intention and naively answers the questions. This might be used by the author to foreground her vulnerability and make the reader infer that she is a typical innocent child. Moreover, in (29) the father does not genuinely ask her opinion and it may be just a rhetorical question, thus breaking the maxim of quality. Papa appears to use it just as a foundation for the further utterances which seem to be the answers to his own question. In such way, Papa also tends not to give a chance for Kambili to convey his views.

(27) "How many heads does she have?"

(28) "How many heads do you have, gbo?", Papa asked ...

(29) "Why do you think I work so hard to give you and Jaja the best?"

(30) "The girl has one head, too, she does not have two. So why did you let her come first?"

On the other hand, only one of Kambili's turns breaks the conversational maxims. It is when the father asks the reason for letting Chinwe Jideze come first in (23). Instead of providing the reason, she declares a statement (24) which can be seen as a promising act. She therefore breaks the maxim of relation and quantity since her answer is not relevant to the question and it is rather uninformative. This response may suggest that Kambili does not have the courage to voice her opinion or argue with her father, thus eventually serving to make the reader infer that she is a quiet or silent daughter.

\subsection{Speech and Thought Presentations}

In this section, I will try to analyze how characters' speech and thought are presented in the extract and how the choices made by the author can affect meanings and viewpoints. The extract begins with a sentence showing physical descriptions and actions. Since it does not involve characters speaking or access to the characters' thoughts, it is thus categorized as Narrator's Representation of Action (henceforth NRA) (Short, 1996). The prime functions of NRA are to describe actions or events conducted by characters or inanimate agents such as in (5), (7) and (31) and to provide descriptions of states including internal states such as in (32). Also, in some circumstances, it can show characters' perceptions. For examples, sentence (11), (12) and (33) portray the narrator's perception by using the perceptive verb taste, watching, and looked respectively, anchoring the description from her point of view. Moreover, there is also one occurrence of Narrator's Representation of Voice (Semino \& Short, 2004). It is in the sentence (34) which describes that there is a verbal activity conducted by a group of girls but we are not informed explicitly about the content of the utterances and what speech acts are performed, thus serving to distance readers from the original speech event.

(31) Her words flew generously out of her mouth

(32) He was gracious, in the eager-to-please way that he always assumed with the religious.

(33) I looked around, feeling a weight around my temples.

(34) A group of girls stood at the door, talking.

The most frequent category of speech presentation in the extract is Direct Speech (henceforth DS). DS is used when the characters' speech is quoted verbatim without any interferences or being filtered by the narrator. It frequently appears within inverted commas followed by a reporting clause such as in (26), (28), (35), and (36). Quotation marks and a reporting clause are features of DS and they can signal the presence of the narrator (Leech \& Short, 2007). However, these two features can be removed to create a freer form of DS which is called "Free Direct Speech" (henceforth FDS). According to Short (1996), (F)DS can enable the author to indicate a more significant speech and more dramatic information. In such way, it is not surprising that sentence (30) that represents Papa's argument, sentence (24) which presents Kambili's answer and sentence (14), (15) and (16) which portray Papa's ideological point of view are in FDS mode with little narrative intervention. This moment might be the most important conversation, representing Papa's deep dissatisfaction and thus foregrounding his extreme ideology.

(35) "She is the girl in the middle," I said.

(36) "Where is your class?" he asked 
On the other hand, Indirect Speech (henceforth IS) is extremely rare. It occurs only in sentence (37) which describes Papa's short conversation with Sister Margaret. Additionally, sentence (38) which show Sister Margaret's questions to Papa appears ambiguous but I tend to interpret it as Free Indirect Speech (henceforth FIS). In this way, Papa's conversation with Sister Margaret seems to be distanced, backgrounded and represented as less important.

(37) He said he had just come to see my class, and Sister Margaret told him to let her know if he needed anything.

(38) Her words flew generously out of her mouth: how was Papa doing, was he happy with my progress at Daughters of the Immaculate Heart, would he be at the reception for the bishop next week?

In terms of thought presentation, the extract contains only Indirect Thought (henceforth IT) and Free Indirect Thought (henceforth FIT) and they are only used to represent the narrator's thoughts. IT occurs in sentence (2), while FIT is employed in (39). However, (2) may be able to be categorized as FIT too since "in I-narrator novels (where the author makes us view everything from that character's stance) the first-person pronoun can occur in FIT because it is appropriate to both the primary and the reported discourse situation" (Leech \& Short, 2007: p. 271). Thus, FIT in both sentences could make the reader feel closer and empathy towards Kambili.

(39) Was Papa going to talk to her? Yank at her ears for coming first?

Moreover, Leech and Short (2007) and Short (1996) describe that IT is the norm for presentation of though, while in presentation of speech, DS is the norm or baseline. This, they argue, is primarily caused by the fact that we cannot directly access to other people thoughts. We can only infer the thoughts of others from their actions, facial expressions, speeches and so on (Short, 1996: p. 315). Similarly, Halliday (1994: p. 253) also argues that IT is the "typical pattern" for describing thoughts and ideas in Language. However, Semino and Short (2004: p. 127) points out that 'FIT' is applied more frequently than IT in twentieth-century fiction. Therefore, the finding of this present extract may contribute to lend weight to their claim.

\subsection{Mind Style}

The notion of "mind style" was introduced by Fowler in 1977. It refers to how systematic linguistic patterns in (part of) a (fictional) text may project a characteristic world view. For fowler (1996), mind style is equal to world view and ideological viewpoints. Nevertheless, in this essay I prefer to use Semino's (2002) definition, namely a "particular" and "personal" means of understanding and making sense of the (fictional) world. It can be stated that Kambili has "normal" or "conventional" mind style. One way to see it is by looking at patterns of transitivity. Transitivity generally describes how participants, processes and circumstances are expressed in the clause. In the extract, Kambili seems to have usual transitivity patterns which represent human as agents of mental and material processes such as in (40) and (41) respectively. The only clause that constructs inanimate as an agent is sentence (31). Sister Margaret's words are ascribed to material process "flew", backgrounding Sister Margaret's agency. Kambili also uses active transitive structures frequently, which might suggest that she has clear understanding of basic activities. Moreover, in terms of grammar, many of the narrative sentences are relatively long, and have complex grammatical structures such as sentence (37), (42), and (43). Analyzing lexical choices can also be means for the projection of mind style, and it can be considered as the most salient technique (Semino, 2005). The vocabulary of Kambili's narrative is rather varied and also contains specific lexical items such as the word manicured in (5), waddled in (41) and peered in (20), which might indicate that she has enough access to relevant concept. The last method is by investigating the use of figurative language. Kambili tends to apply conventional figurative language such as simile in sentence (43), comparing "a light dust Ikuku in brown spirals with uncoiling springs", and personification in sentence (44), giving a human characteristic (swallow) to inanimate object (ground). What might be inferred from these linguistic patterns is that Kambili tends to be represented as having a mind style of a smart teenager, rather than child-like mind style. This might help make the reader infer that although she comes second, she is still an excellent student so that her father extreme disappointment to her achievement is not appropriate. In such way, the reader may feel more sympathetic towards Kambili.

(40) Sister Margaret saw him as he walked to my class.

(41) She waved gaily, from the midst of students and a few parents, then quickly waddled over to us.

(42) Papa changed his accent when he spoke, sounding British, just as he did when he spoke to Father Benedict.

(43) A light dust Ikuku was blowing, in brown spirals like uncoiling springs, and I could taste the sand that settled on my lips.

(44) I wanted the ground to open up and swallow the whole compound.

\section{Conclusion}

This study has attempted to carry out a systematic stylistic analysis of Purple Hibiscus extract. It has focused on a number of linguistic aspects which appear more significant and salient in the understanding of the extract. More precisely, I have endeavored to investigate how points of view, turn-taking patterns, pragmatic features, speech and thought presentations, and mind style are used by Chichamanda Ngozi Adichie to construct personalities of the characters and relationships between them in the reader's imagination. The result may suggest that in the present extract the author wants to represent the narrator or Kambili as an obedient and a salient daughter who respects deeply his father, while her father (Papa) is constructed as a strict father and religious who insists an absolute control on his daughter. 
Acknowledgement

The author would like to express profound gratitude to Indonesia Endowment Fund for Education (LPDP) for funding this study.

\section{References}

Abdurrahman, I. B. (2016). A stylistic analysis of complexity in William Faulkner's "A Rose for Emily". Advances in Language and Literary Studies, 7(4), 220-230. doi:10.7575/aiac.alls.v.7n.4p.220

Adichie, C. N. (2003). Purple Hibiscus. Chapel Hill: Algonquin Books.

Brown, P., \& Levinson, S. C. (1978). Universals in language usage: Politeness phenomena. In E. N. Goody (Ed.), Questions and Politeness: Strategies in Social Interaction (pp. 56-289). Cambridge: Cambridge University Press.

Brown, P., \& Levinson, S. C. (1987). Politeness: Some Universals in Language Usage. Cambridge: Cambridge University Press.

Cutting, J. (2008). Pragmatics and Discourse: A Resource Book for Students (2nd ed.). Abingdon: Routledge.

Fowler, R. (1986). Linguistic Criticism. Oxford: Oxford University Press.

Fowler, R. (1996). Linguistic Criticism (2nd ed.). Oxford: Oxford University Press.

Grice, H. P. (1975). Logic and Conversation. In P. Cole \& J. L. Morgan (Eds.), Syntax and Semantics 3: Speech Acts (pp. 41-58). New York: Academic Press.

Grice, H. P. (1989). Studies in the way of words. Cambridge, Massachusetts: Harvard University Press.

Grice, H. P. (2011). Logic and Conversation. In D. Archer \& P. Grundy (Eds.), The Pragmatics Reader (pp. 43-54). Abingdon: Routledge.

Guo, H. (2017). Isolation and communication A stylistic snalysis of thought presentation in Mrs. Dalloway. Advances in Language and Literary Studies, 8(1), 167-175. doi:10.7575/aiac.alls.v.8n.1p.167

Halliday, M. A. K. (1985). An Introduction to Functional Grammar. London: E. Arnold.

Halliday, M. A. K. (1994). An Introduction to Functional Grammar (2nd ed.). London: E. Arnold.

Leech, G. N., \& Short, M. (2007). Style in Fiction: A Linguistic Introduction to English Fictional Prose (2nd ed.). London: Longman.

Semino, E. (1997). Language and World Creation in Poems and Other Texts. London: Longman.

Semino, E. (2002). A cognitive stylistic approach to mind style in narrative fiction. In E. Semino \& J. Culpeper (Eds.), Cognitive Stylistics: Language and Cognition in Text Analysis (pp. 95-122). Amsterdam: John Benjamins.

Semino, E. (2005). Mind style. Elsevier Encyclopaedia of Language and Linguistics.

Semino, E., \& Short, M. (2004). Corpus Stylistics: Speech, Writing and Thought Presentation in a Corpus of English Writing. London: Routledge.

Short, M. (1996). Exploring the Language of Poems, Plays, and Prose. London: Longman.

Short, M. (2014). Analysing dialogue. In P. Stockwell \& S. Whiteley (Eds.), The Cambridge Handbook of Stylistics (pp. 344-359). Cambridge: Cambridge University Press.

Simpson, P. (1993). Language, Ideology, and Point of View. London: Routledge.

Simpson, P. (2014). Stylistics: A Resource Bookfor Students (2nd ed. ed.). Abingdon: Routledge.

Stobie, C. (2010). Dethroning the infallible father: Religion, patriarchy and politics in Chimamanda Ngozi Adichie's Purple hibiscus. Literature and Theology, 24(4), 421-435.

Teranishi, M. (2007). A stylistic analysis of Saul Bellow's Herzog: A mode of 'Postmodern Polyphony'. Language and Literature, 16(1), 20-36. doi:10.1177/0963947007068655

Tunca, D. (2009). An ambiguous "Freedom Song": Mind-style in Chimamanda Ngozi Adichie's Purple Hibiscus. Postcolonial Text, 5(1), 18 pages.

\section{Appendix}

Purple Hibiscus, by Chichamanda Ngozi Adichie, 2004, pp. 45-48)

Papa finally eased the car into the wide school compound and parked near the volleyball court, beyond the stretch of manicured lawn.

"Where is your class?" he asked. 
I pointed to the building by the group of mango trees. Papa came out of the car with me and I wondered what he was doing, why he was here, why he had driven me to school and asked Kevin to take Jaja.

Sister Margaret saw him as he walked to my class. She waved gaily (happily), from the midst of students and a few parents, then quickly waddled over to us. Her words flew generously out of her mouth: how was Papa doing, was he happy with my progress at Daughters of the Immaculate Heart, would he be at the reception for the bishop next week?

Papa changed his accent when he spoke, sounding British, just as he did when he spoke to Father Benedict. He was gracious, in the eager-to-please way that he always assumed with the religious. As gracious as when he presented the check for refurbishing the Daughters of the Immaculate Heart library. He said he had just come to see my class, and Sister Margaret told him to let her know if he needed anything.

"Where is Chinwe Jideze?" Papa asked, when we got to the front of my class. A group of girls stood at the door, talking. I looked around, feeling a weight around my temples. What would Papa do? Chinwe's light-skinned face was at the center of the group, as usual.

"She is the girl in the middle," I said. Was Papa going to talk to her? Yank at her ears for coming first? I wanted the ground to open up and swallow the whole compound.

"Look at her," Papa said. "How many heads does she have?"

"One." I did not need to look at her to know that, but I looked at her, anyway.

Papa pulled a small mirror, the size of a powder compact, from his pocket. "Look in the mirror."

I stared at him.

"Look in the mirror."

I took the mirror, peered at it.

“How many heads do you have, gbo?” Papa asked, speaking Igbo for the first time.

"One."

"The girl has one head, too, she does not have two. So why did you let her come first?"

"It will not happen again, Papa." A light dust Ikuku was blowing, in brown spirals like uncoiling springs, and I could taste the sand that settled on my lips.

"Why do you think I work so hard to give you and Jaja the best? You have to do something with all these privileges. Because God has given you much, he expects much from you. He expects perfection. I did not have a father who sent me to the best schools. My father spent his time worshiping gods of wood and stone. I would be nothing today but for the priests and sisters at the mission. I was a houseboy for the parish priest for two years. Yes, a houseboy. Nobody dropped me off at school. I walked eight miles every day to Nimo until I finished elementary school. I was a gardener for the priests while I attended St. Gregory's Secondary School."

I had heard this all before, how hard he had worked, how much the missionary Reverend Sisters and priests had taught him, things he would never have learned from his idol-worshiping father, my Papa-Nnukwu. But I nodded and looked alert. I hoped my class girls were not wondering why my father and I had chosen to come to school to have a long conversation in front of the classroom building. Finally, Papa stopped talking and took the mirror back.

"Kevin will be here to pick you up," he said.

"Yes, Papa."

"Bye. Read well." He hugged me, a brief side hug.

"Bye, Papa." I was watching him walk down the path bordered by flowerless green bushes when the assembly bell rang. 